\title{
Uji Efektivitas Ekstrak Paku Pedang (Nephrolepis exaltata) Terhadap Pertumbuhan Jamur Candida albicans
}

\section{The Effectiveness of The Sword Spikes (Nephrolepis exaltata) Extract Against The Growth of The Fungus Candida albicans}

\author{
Diana Mey Merlina ${ }^{1}$, Ngadiani ${ }^{2}$ \\ ${ }^{1}$ Mahasiswa Prodi Biologi FMIPA Universitas PGRI Adi Buana Surabaya \\ ${ }^{2}$ Staf Pegajar Prodi Biologi FMIPA Universitas PGRI Adi Buana Surabaya \\ Email: meydiana.diana.mey@gmail.com ${ }^{1}$, ngadiani@unipasby.ac.id ${ }^{2}$
}

\begin{abstract}
Abstrak
Tanaman Paku Pedang (Nephrolepis exaltata) merupakan tumbuhan paku dalam suku Lomariopsidaceae yang mudah dijumpai tumbuh di tepi - tepi sungai, tebing, dan mengandung senyawa flavonoid dan alkaloid yang dapat menghambat pertumbuhan jamur Candida albicans. Penelitian ini bertujuan untuk mengetahui efektifitas ekstrak paku pedang (Nephrolepis exaltata) terhadap pertumbuhan jamur Candida albicans. Penelitian ini merupakan jenis penelitian Kuantitatif bersifat eksperimental laboratories menggunakan Rancangan Acak Lengkap (RAL) dengan 4 kelompok perlakuan yang berbeda, 1 kontrol negatif (Pz Steril) dan 1 kontrol positif (Ketokenazol). Parameter yang diamati ialah jumlah rata - rata koloni (CFU) dan rata - rata luas zona hambat (mm). Data dianalisis dengan software SPSS menggunakan analisis varian satu arah yang dilanjutkan dengan uji menggunakan DMRT. Hasil menunjukkan semua konsentrasi berbeda dengan kontrol negatif, sedangkan konsentrasi ekstrak 1000 ppm dibandingkan dengan kontrol positif tidak ada perbedaan. Ekstrak paku pedang (Nephrolepis exaltata) memiliki pengaruh terhadap pertumbuhan jamur Candida albicans yaitu jumlah koloni sebesar 6,78 CFU $\left(6 \times 10^{6}\right)$ pada konsentrasi 1000 ppm dan zona hambat 33,10 mm pada konsentrasi 1000 ppm.
\end{abstract}

Kata kunci : Candida albicans, Paku Pedang (Nephrolepis exaltata), Zona Hambat, Jumlah Koloni

\begin{abstract}
Plant swords (Nephrolepis exaltata) are ferns in the Lomariopsidaceae tribe which are easily found on the banks of rivers, cliffs, and contain flavonoids and alkaloids that can inhibit the growth of albicans candida fungi. This study aims to determine the effectiveness of Sword nail extract (Nephrolepis exaltata) on the growth of albicans candida fungi. This research is a quantitative laboratory experimental type using a completely randomized design (RAL) with 4 different treatment groups, 1 negative control ( $p z$ sterile) and 1 positive control (ketocenazole). The parameters observed were the number of colonies (CFU) and the average area of the inhibition zone (mm). The data was analyzed using SPSS software using one way ANOVA analysis which was then followed by a test using DMRT. The results showed that all concentrations differed from the negative controls, while the extract concentration of 1000 ppm compared to the positive controls had no difference. Sword nail extract (Nephrolepis exaltata) has an influence on the growth of candida albicans mushrooms, namely the number of colonies of 6.78 CFU $\left(6 \times 10^{6}\right)$ at a concentration of $1000 \mathrm{ppm}$ and inhibition zone $33.10 \mathrm{~mm}$ at a concentration of $1000 \mathrm{ppm}$.
\end{abstract}

Keywords : Candida albicans, Sword spikes (Nephrolepis exaltata), Inhibitory Zone, Colony Count.

PENDAHULUAN

Penelitian ini dilakukan dengan menggunakan kandungan flavonoid yang telah diuji pada uji fitokimia yang terdapat dalam ekstrak tanaman paku pedang yang banyak dijumpai di rumah - rumah untuk mengobati penyakit kulit, salah satu contohnya adalah penyakit panu. Penyakit panu merupakan salah satu penyakit kulit yang sering dialami oleh masyarakat dan disebabkan oleh jamur candida.
Tanaman paku pedang (Nephrolepis sp.) memiliki kandungan senyawa kimia antara lain saponin, kardenolin, flavonoid dan tannin (Dayanti dan Suyatno,2012).

Candida ialah suatu genus ragi, yang menjadi penyebab penyakit kandidiasis. Kandidiasis ialah infeksi primer atau sekunder dari Candida albicans. Candida merupakan flora normal penghuni rongga mulut yang bersifat oppurtunistik dan dapat menjadi dominan dan menginfeksi apabila keseimbangan flora dan kebersihan mulut 
terganggu atau daya tahan tubuh melemah (immunodeficiency). Lebih dari 150 spesies Candida telah teridentifikasi dan sebanyak paling sedikit tujuh puluh persen kandidiasis disebabkan oleh $C$. albicans (Kandoli, 2016).

Penggunaan anti fungi secara luas dapat mengakibatkan peningkatan jumlah pasien yang alergi dan resisten. Resistensi fungi dapat terjadi jika pengobatan dengan antifungi terlalu singkat atau terlalu lama dengan dosis yang rendah. Obat antifungi peoral sering menimbulkan efek samping yaitu berupa mual, pusing, demam, muntah, diare dan kerusakan pada kulit. Dalam pemakaian jangka panjang, akan menyebabkan gangguan fungsi ginjal dan kerusakan ginjal yang menetap disebabkan karena efek toksik. Untuk mengurangi penggunaan antifungi sintetik dibutuhkan suatu alternatif yaitu menggunakan antifungi alami yang bersumber dari tumbuhan, untuk menghambat atau membunuh pertumbuhan fungi (Puspa, 2018)

\section{MATERI DAN METODE PENELITIAN}

Penelitian ini dilakukan secara kuantitatif laboratories bersifat eksperimen laboratorium yang bertujuan untuk mengetahui pengaruh, Konsentrasi Hambat Minimum (KHM) dan Jumlah Koloni ekstrak Nephrolepis exaltata terhadap pertumbuhan $C$. albicans.

\section{Penyiapan Bahan}

Daun paku pedang diambil di Kebraon, Kecamatan Karang Pilang, Surabaya. Jamur uji yang digunakan pada penelitian ini adalah kultur murni C.albicans yang merupakan koleksi dari Unit Laboraturium Mikrobakteriologi Universitas Ma'arif Hasyim Latif Sidoarjo.

\section{Prosedur Penelitian}

Penelitian ini dilakukan menggunakan rancangan acak lengkap (RAL) dengan 4 perlakuan dan 5 kali pengulangan untuk zona hambat serta hitung jumlah koloni C.albicans dengan 3 pengulangan dan 4 pengenceran konsentrasi.
Simplisia serbuk Nephrolepis sebanyak $20 \mathrm{~g}$ dimaserasi dengan pelarut etanol $96 \%$ sebanyak 4 konsentrasi (700 ppm, 800 ppm, 900 ppm, dan 1000 ppm). Kertas cakram yang telah direndam selama 15 menit pada masing - masing konsentrasi. Kemudian ditanam pada media Sabouraud Dextrose Agar (SDA), inkubasi selama 3-5 hari dalam suhu ruang.

Perhitung jumlah koloni dibuat pengenceran seri. Pengenceran dilakukan dengan cara mengambil $1 \mathrm{ml}$ suspense $C$. albicans yang telah dilakukan pengukuran dengan menggunakan standart Mc Farland, lalu dicampurkan dengan larutan $\mathrm{NaCl} 9 \mathrm{ml}$, sehingga diperoleh larutan dengan tingkat pengenceran $10^{-1}$. Larutan pada tingkat pengenceran $10^{-1}$ diambil sebanyak $1 \mathrm{ml}$ dan dihomogenkan dengan $9 \mathrm{ml} \mathrm{NaCl}$, sehingga diperoleh larutan dengan tingkat pengenceran $10^{-2}$, begitu seterusnya sampai pada tingkat pengenceran $10^{-6}$. Masing masing suspense sebanyak $0,1 \mathrm{ml}$ disebarkan dan diratakan pada cawan petri berisi media SDA dengan menggunakan batang sebar. Setiap suspensi diinkubasikan pada suhu $37^{\circ} \mathrm{C}$ selama 24 jam dan diamati jumlah koloninya. Jumlah koloni $C$. albicans yang dipilih memiliki jumlah koloni antara 30 - 300 koloni.

Kelompok perlakuan 1 terdiri dari $1 \mathrm{ml}$ ekstrak Nephrolepis dengan konsentrasi 700 ppm ditambahkan dengan $0,1 \mathrm{ml}$ suspense C. albicans. Kelompok perlakuan 2 terdiri dari $1 \mathrm{ml}$ ekstrak Nephrolepis dengan konsentrasi 800 ppm ditambahkan dengan 0,1 $\mathrm{ml}$ suspensi $C$. albicans, begitu seterusnya sampai konsentrasi 1000 ppm. Kelompok kontrol positif (+) terdiri dari 1 $\mathrm{ml}$ Ketokenazol ditambahkan dengan 0,1 ml suspensi $C$. albicans. Kelompok kontrol negative (-) terdiri dari $1 \mathrm{ml}$ aquadest ditambahkan dengan $0,1 \mathrm{ml}$ suspense $C$. albicans.

Masing - masing tabung diambil 0,1 ml suspensi dengan menggunakan mikropipet dan tanam dengan menggunakan metode spread plate pada media SDA, kemudian diinkubasi pada suhu $37^{\circ} \mathrm{C}$ selama 48 jam, koloni yang terbentuk 
pertumbuhannya dihitung dengan menggunakan colony counter Konsentrasi Bunuh Minimum (KBM) adalah pada SDA yang sama sekali tidak terdapat pertumbuhan $C$. albicans (Silvia, et al, 2017).

Khamir C. albicans media SDA berbentuk bulat atau oval yang biasa disebut bentuk khamir dengan ukuran $(3,5-6) \times(6-$ 10) $\mu \mathrm{m}$, koloni berwarna krem, agak mengkilat dan halus (Kusumaningtyas, 2013).

\section{Analisis Statistika}

Data yang terkumpul dianalisis menggunakan analisis varian sesuai dengan rancangan penelitian (RAL) menggunakan perangkat lunak SPSS 23. Letak perbedaan antara perlakuan diuji lanjut dengan uji jarak berganda Duncan.

\section{HASIL PENELITIAN}

\section{Zona Hambat Ekstrak Nephrolepis} exaltata terhadap Candida albicans

Hasil penelitian menunjukkan bahwa pemberian ekstrak paku pedang berpengaruh signifikan $(\mathrm{P}<0,05)$ terhadap daya hambatan jamur Candida albicans ( $\mathrm{p}<0,05)$. Gambar 1 menunjukkan rata - rata zona hambat pada konsentrasi $1000 \mathrm{ppm}(33.100 \pm 0.42485)$ signifikan $\quad(\mathrm{p}<0,05) \quad$ lebih tinggi dibandingkan rata - rata zona hambat pada konsentrasi $700 \mathrm{ppm}(23.162 \pm 0.34434)$, $800 \mathrm{ppm}$ (29.094 \pm 0.52729$)$, dan $900 \mathrm{ppm}$ (30.974 \pm 0.61918$)$.

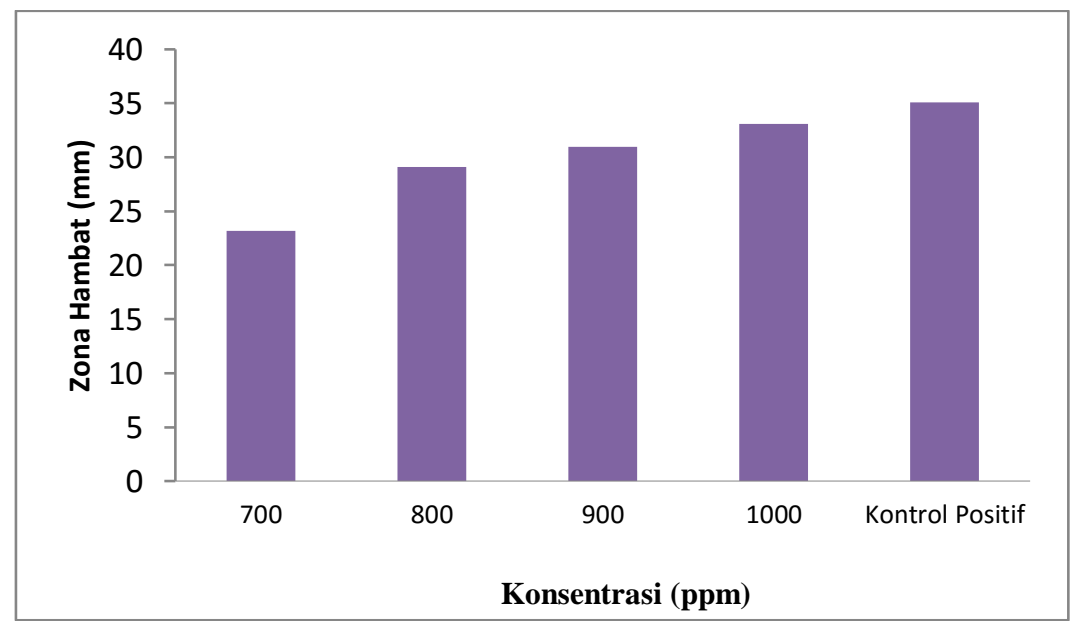

Gambar 1 Zona hambat ekstrak Paku Pedang

Jumlah Koloni Candida albicans Pada Berbagai Konsentrasi Ekstrak Nephrolepis exaltata (CFU) (Hasil Transformasi Data)

Hasil penelitian menunjukkan bahwa perlakuan pemberian ekstrak paku pedang berpengaruh signifikan $(\mathrm{P}<0,05)$ terhadap jumlah koloni $C$. albicans. Gambar 2 menunjukkan bahwa rata-rata jumlah koloni yaitu: $700 \mathrm{ppm}(7.72 \pm 0.01732 \mathrm{CFU}), 800$ ppm (7.56 \pm 0.03606 CFU), 900 ppm (7.32 $\pm 0.04000 \mathrm{CFU})$, dan $1000 \mathrm{ppm}(6.78 \pm$ $0.15100 \mathrm{CFU})$. 


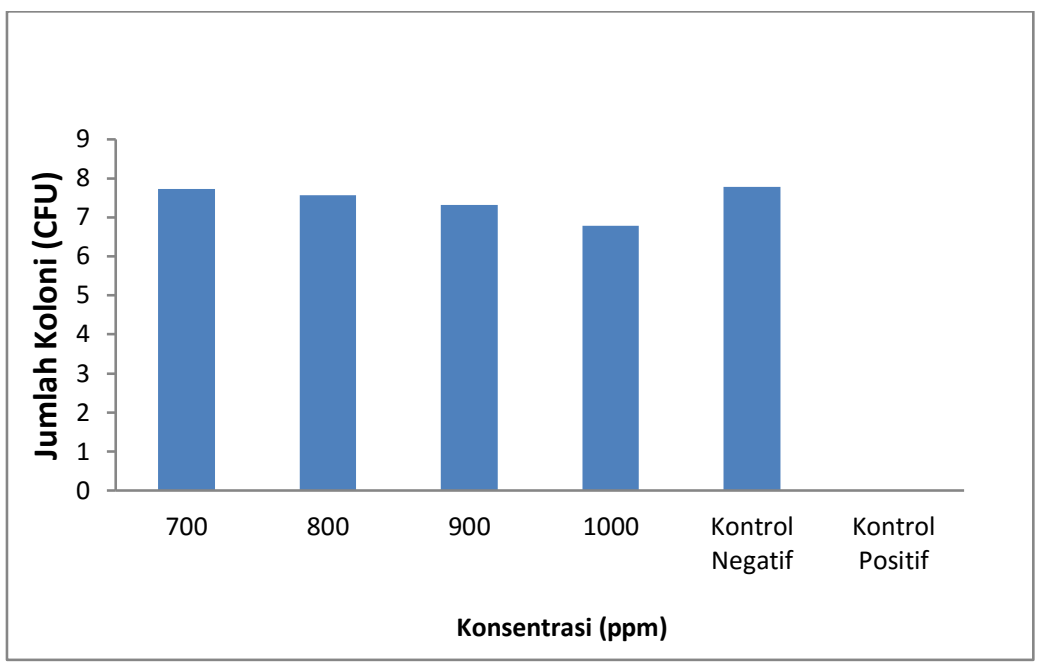

Gambar 2 Jumlah Koloni Candida albicans Pada Berbagai Konsentrasi Ekstrak Paku Pedang

\section{PEMBAHASAN}

Berdasarkan kriteria kekuatan antifungi dalam NCCLS (2008) daya antifungi ketokenazole $10 \mu \mathrm{g}$ dengan rerata 35,12 mm termasuk kategori kuat. Ekstrak paku pedang konsentrasi 700 ppm, 800 ppm, $900 \mathrm{ppm}$, dan $1000 \mathrm{ppm}$ memiliki rerata diameter zona hambat $23,16 \mathrm{~mm} ; 29,09 \mathrm{~mm}$; $30,97 \mathrm{~mm}$; dan $33,10 \mathrm{~mm}$, dan tiap konsentrasi memiliki perbedaan yang signifikan, menurut kriteria kekuatan antifungi NCCLS (2008) diameter zona hambat dengan perlakuan ekstrak paku pedang 700 ppm termasuk kriteria sedang, sedangkan perlakuan ekstrak paku pedang 800 ppm, 900 ppm dan 1000 ppm termasuk kriteria kuat.

\begin{tabular}{ccc}
\hline No & $\begin{array}{c}\text { Diameter Zona } \\
\text { Hambat }(\mathbf{m m})\end{array}$ & $\begin{array}{c}\text { Aktivitas } \\
\text { Antufungi }\end{array}$ \\
\hline $\mathbf{1}$ & $\geq 28$ & Kuat \\
$\mathbf{2}$ & $21-27$ & Sedang \\
$\mathbf{3}$ & $\leq 20$ & Lemah \\
\hline
\end{tabular}

Berdasarkan hasil penelitian dapat diinformasikan bahwa ekstrak paku pedang memiliki zona hambat yang hampir sama dengan ketokenazole sehingga efektif digunakan sebagai antifungi untuk meghambat pertumbuhan jamur Candida albicans.

Berdasarkan data yang didapatkan bahwa ekstrak paku pedang dapat menghambat $C$. albicans karena paku pedang mengandung senyawa kimia seperti flavonoid dan alkaloid. Daya antifungi ini disebabkan oleh adanya senyawa kimia flavonoid dan alkaloid (Kurniawan, et ala, 2016).

Menurut Kurniawan, (2016) mekanisme senyawa flavonoid berperan sebagai antifungi. Flavonoid dilaporkan berperan sebagai antivirus, antibakteri, antifungi, antiradang dan antialergi. Flavonoid merupakan metabolit sekunder pada daun paku pedang yang berfungsi mendenaturai protein sel jamur dan bersifat lipofilik. Mekanisme kerja flavonoid dengan cara denaturasi protein, mengganggu lapisan lipid dan mengakibatkan kerusakan dinding sel. sifat lipofilik pada flavonoid tersebut yang akan mengikat fosfolipid-fosfolipid pada membrane sel jamur dan mengganggu permeabilitas membran sel (Kurniawati, 2016). Sedangkan menurut Kurniawan, (2016) mekanisme senyawa alkaloid dapat menghambat sintesis asam nukleat dan mempengaruhi ergosterol pada $C$. albicans. 


\section{SIMPULAN DAN SARAN SIMPULAN}

1. Terdapat Pengaruh Ekstrak Paku Pedang (Nephrolepis exaltata) terhadap pertumbuhan Candida albicans

2. Ekstrak Nephrolepis exaltata efektif menghambat pertumbuhan jamur Candida albicans pada konsentrasi $1000 \mathrm{ppm}$ dengan hasil zona hambat 33,10 mm dan jumlah koloni 6,78 CFU (6x106 CFU).

\section{SARAN}

Diharapkan dapat digunakan untuk penelitian selanjutnya dan dilakukan penelitian lebih lanjut berdasarkan sampel yang berbeda.

\section{DAFTAR PUSTAKA}

Bais, H. P., Walker, T. S., Schweizer, H. P., Vivanco, J. M. 2002. Root Specific Elication and Antimicrobial Activity of Rosmarinic Acid In Hairy Root Culture of Ocimum basilicum. Journal of Plant Physiol Biochrm. 40:983.

Dayanti, R dan Suyatno, 2012. Aktivitas Antioksidan Ekstrak Metanol Bagian Batang Tumbuhan Paku Neprholepis radicans (BURM.) KUHN. Jurusan Kimia FMIPA, Universitas Negeri Surabaya.

Desmara S. 2017. Konsentrasi Hambat Minimum dan Konsentrasi Bunuh Minimum Ekstrak Daun Kemangi (Ocimum Sanctum L.) Terhadap Pertumbuhan Candida Albicans. Program Studi Pendidikan Kedokteran Gigi. Fakultas Ilmu Kedokteran Gigi. Universitas Syiah Kuala, Aceh.

Fikri, K. D., 2012. Penggunaan Tanaman $\mathrm{Apu}$ - Apu Untuk Pengobatan Penyakit Kulit (Panu). Jurnal Akademi Leksono, P., 2006. Aktivitas Ekstrak Daun Pandan Wangi (Pandanus amaryllifolius) Sebagai Antifungi Candida Albicans. Program studi Biologi FMIPA. Universitas Pakuan, Bogor.
Analis Farmasi dan Makanan Putra Indonesia Malang.

Hana Z. H. 2018. Efektifitas Ekstrak Daun Azolla microphylla Terhadap Pertumbuhan Candida albicans. [Skripsi]. Universitas Adibuana, Surabaya.

Juhaeriah, E. 2013. Uji Toksisitas Akut Ekstrak Etanol Daun Paku Pedang (Nephrolepis falcata) Terhadap Larva Artemia Salina Leach Dengan Metode Brine Shrimp Lethaly Test (BSLT). [Skripsi]. Fakultas Kedokteran dan Ilmu Kesehatan. Universitas Islam Negeri Syarif Hidayatullah Jakarta.

Kandoli, F., Abijulu, J., Leman, M. 2016. Uji Daya Hambat Ekstrak Daun Durian (Durio zybethinus) Terhadap Pertumbuhan Candida albicans Secara In Vitro. Prodi Kedokteran Gigi, Fakultas Kedokteran UNSRAT Manado.

Katzung, B. G., Susan, M. B., dan Anthony. 2013. Farmakologi dasar dan Klinik Edisi 12 Volume 1. Jakarta : Buku Kedokteran EGC.

Kurniawan, J.A. 2009. Uji Aktivitas Antijamur Ekstrak Rimpang Binahong (Anredera cordifolia (tenore) Terhadap Jamur Candida albicans serta Skrining Fitokimianya. Fakultas Farmasi Universitas Muhammadiyah Surakarta.

Kurniawan, D. 2015. Uji Aktivitas Antijamur Ekstrak Etanol Daun Kelor (Moringa oleifera Lamk.) Terhadap Candida albicans Secara In Vitro. Naskah Publikasi. Program Studi Pendidikan Dokter. Fakultas Kedokteran. Universitas Tanjungpura Pontianak.

Ngadiani. 2015. Paku-pakuan Edisi Pertama. ISBN 978-979-8559-64-8. Adibuana Universitas Press. Surabaya. Pratiwi, S. T. 2008. Mikrobiologi Farmasi. Jakarta : Penerbit Erlangga.

Rahayu, P. 2013. Konsentrasi Hambat Minimum Buah Belimbing Wuluh (Averrhoa bilimbi L.) Terhadap 
Pertumbuhan Candida albicans. Fakultas Kedokteran Gigi Universitas Hasanuddin Makassar.

Van Steenis, C.G.G.J., 2008. Flora. PT. Pradnya Paramita. Jakarta.

Waluyo, L. 2008. Mikrobiologi Umum. Malang : UMM Press.

Widyaningrum, T. 2015. Uji Aktivitas Antifungi Ekstrak Etanol Daun Sidaguri (Sida rhombifolia) Terhadap Candida albicans. Prosiding Seminar Nasional Pendidikan Biologi, Universitas Ahmad Dahlan, Yogyakarta.
Yenny P. R. 2018. Uji Efektifitas Ekstrak Kayu Apu (Pistia stratiotes) Terhadap Pertumbuhan Jamur Candida albicans Secara In Vitro. [Skripsi]. Universitas Adibuana, Surabaya.

Yunita, D., dan Rosada, A., 2009. Identifikasi dan Klasifikasi Tumbuhan Paku di Perkebunan Karet (Hevea brasiliensis) di Desa Tanjung Raya Kecamatan Rambang Prabumulih Sumatera Selatan. Fakultas MIPA Universitas PGRI Palembang. 